\title{
ПСИХОЛОГІЧНІ МЕХАНІЗМИ ФОРМУВАННЯ МІЖОСОБИСТІСНИХ СТОСУНКІВ У ВИХОВАНЦІВ- ПІДЛІТКІВ ДИТЯЧОГО БУДИНКУ СІМЕЙНОГО ТИПУ
}

\author{
УДК: 159.922.27-053.6:37.018.3
}

\section{Чистяк Ольга Володимирівна}

\author{
Аспірант кафедри психологї і педагогіки \\ Факультету педагогіки і психології, \\ Начіональний педагогічний університет імені \\ М. П. Драгоманова, Київ (Україна)
}

\begin{abstract}
Анотація. У статті здійснено теоретичний аналіз наукових досліджень міжсособистісного спілкування в підлітковому віці. Визначено особливості взаємин вихованиівпідлітків дитячого будинку сімейного типу. Проаналізовано структуру формування міжособистісних стосунків. Подана характеристика типів міжособистісних взаємин в підлітковому віці. У статті розглянуто механізми формування міжособистісних стосунків вихованців-підлітків в умовах дитячого будинку сімейного типу. Охарактеризовано міжособистісні стосунки між однолітками, батьками-вихователями, іншими прийомними дітьми. Розглянуто механізми взаємовпливу в міжособистісних стосунках вихованців - підлітків. Розкрито алгоритм формування міжособистісних стосунків вихованців - підлітків на основі демократичного стилю виховання у дитячому будинку сімейного типу. Презентовано компоненти міжособистісних стосунків та розкрито їх зміст.
\end{abstract}

Ключові слова: міжособистісні стосунки; підлітковий вік; структура формування міжособистісних взаємин; механізми міжособистісних стосунків.

Постановка проблеми. 3 кожним роком у країні зростає кількість дітей-сиріт та дітей, позбавлених батьківської опіки. Головною характеристикою стабільного психологічного стану таких дітей $є$ міжособистісне ставлення до батьків-вихователів та однолітків. Для підліткового віку характерна зміна поведінки і надбання нових рис характеру та соціальних принципів, відповідно до нової сім'ї. Вихованець-підліток усвідомлює свою приналежність до світу дорослих, з’являється усві- домлення свого «Я», по-дорослому оцінює ту чи іншу ситуацію.

Аналіз досліджень і публікацій. Дослідженням міжособистісних стосунків дітейпідлітків $\epsilon$ в роботах таких українських вчених, як : О. Білецької [18], Л. Василенка [10], Л. Долинської [1], І. Долі [2], М. Заброцького [3], О. Конанка [5], В. Кутішенка [6], Г. Лактіонова [7], 3. Огороднічука [1], М. Савчина [10], О. Скрипченка [1], М. Малькова [8], I. Пєши [12], М. Ясеновської [18] та інших. Ра- 
зом із цим, залишається недостатньо дослідженою проблема формування міжособистісних стосунків дітей-підлітків, які виховується в дитячих будинках сімейного типу.

Метою статті $\epsilon$ характеристика міжособистісних стосунків дітей-підлітків в дитячих будинках сімейного типу, типів таких стосунків та механізмів взаємовпливу, презентація алгоритму формування міжособистісних стосунків вихованців - підлітків на основі демократичного стилю виховання у ДБСТ .

Виклад основного матеріалу. Дитячий будинок сімейного типу (далі - ДБСТ) окрема сім'я, що створюється за бажанням подружжя або окремої особи, яка не перебуває у шлюбі, для забезпечення сімейним вихован-ням та спільного проживання не менш як п'яти дітей-сиріт і дітей, позбавлених батьківського піклування [1, с. 195].

Основна ідея, яка формує позитивний образ сім'ї у вихованців - це створення певного реабілітаційного життєвого простору для дітей, своєрідної моделі сімейних відносин, тобто такого зразка «власного будинку» для дитини, який міг би допомогти йому підготуватися до виходу у доросле життя й забезпечити успішну адаптацію в соціумі.

Варто зазначити, що підлітковий вік період становлення якісно нових взаємин із дорослими. Вихованці-підлітки вже, як правило, не погоджуються на характерні для дитинства нерівноправні стосунки, оскільки вони не відповідають їх уявленням про власну дорос- лість та самостійність. Вони вимагають поваги до власної особистості та людської гідності, довіри та самостійності, тобто істотно обмежують права дорослого та розширюють свої власні $[2$, с. 56].

Підлітковий вік характеризується емоційною нестабільністю, підвищеною збудливістю, нестійкістю емоцій власної поведінки, підлітки погано контролюють себе, емоційнонестабільні, що зумовлює підвищення агресивності, конфліктності та імпульсивності поведінки. Підлітки часто спочатку роблять, а вже потім думають про зроблене, хоч і усвідомлюють при цьому, що слід було вчинити навпаки, раптово можуть змінюватись емоційні стани підлітка, з різними переходами від надмірної рухливості до спокою, від піднесення до байдужості. Важливим $є$ те, що даний період дозволяє молодій людині вийти на нову соціальну позицію, в якій формується ії свідоме ставлення до себе як до члена суспільства $[9$, c. 243].

Вихованці-підлітки все частіше нехтують розпорядженнями дорослого - протестують за зміну існуючого типу стосунків, що породжує конфлікти, непорозуміння та труднощі у спілкуванні дорослого з вихованцем ДБСТ.

Перехід від дитячого стану до стану дорослості - підвищує самостійність вихованців-підлітків, збільшує їх прагнення до самостійності у вирішенні своїх проблем: коли, де, 3 ким спілкуватись, в який час вчити уроки, 
що робити тощо. Чим доросліший стає підліток, тим ця самостійність гостріше проявляється. Іноді можна стверджувати, що дитина навмисно не визнає авторитету батьків, і суперечить їм в усьому [9, с. 80].

Конфліктність при переході до нового типу взаємин виявляється тоді, коли зміни в розвитку особистості вихованця-підлітка випереджають необхідні корективи стосунків 3 дорослими; коли ініціатором змін виступає підліток, а дорослі щосили цьому протидіють [6, с. 90].

Міжособистісні стосунки вихованцівпідлітків ДБСТ - це сукупність об'єктивних зв'язків та взаємодій між особами, які належать до певної групи. Характерною ознакою міжособистісних стосунків $є$ їх емоційне забарвлення. Отже, ми можемо визначити їх як взаємини людей, що формуються в процесі безпосередньої взаємодії в групі, мають неформальний характер i містять емоційнозабарвлену та обопільно-значущу оцінку партнерів по спілкуванню [7, с. 78].

Особливості міжособистісних стосунків вихованців-підлітків ДБСТ проявляються через механізми спілкування з дорослими, спілкування із однолітками в межах ДБСТ та поза його межами.

Спілкування вихованців-підлітків 3 дорослим характеризується :

- рівнянням на дорослого;

- $\quad$ критичним ставленням до зауважень;

- $\quad$ прагнення до самостійності, яке перерос- тає у конфлікт з дорослими.

Спілкування вихованців-підлітків 3 іншими вихованцями ДБСТ характеризується прагненням мати серед них авторитет та наслідувати їхню поведінку.

Міжособистісні стосунки підлітків мають такі компоненти: 1) мотиваційний; 2) емоційно-вольовий; 3) інструментальний.

1. Мотиваційний компонент міжособистісних стосунків вихованців дитячого будинку сімейного типу, включає в себе мотив інтересу, зокрема пізнавального, мотив афіліації, мотив досягнень, мотив саморозвитку.

2. Емоційно-вольовий компонент складають емоційно-вольові якості, які на наш думку, впливають на характер та якість міжособистісних стосунків. Так, надмірна стриманість вихованця у стосунках призводить до того, що дитина сприймається як холодна, байдужа, зарозуміла. В одних випадках це викликає тільки здивування, в інших - породжує неприязнь і стає перешкодою для встановлення нормальних відносин між дітьми. Можна стверджувати, що однією $з$ головних проблем соціального розвитку дитини-сироти $€$ iii здатність адекватно виражати свої почуття у відповідний момент і з належною інтенсивністю.

3. Інструментальний компонент міжособистісних стосунків передбачає наявність здатності грамотно, переконливо висловлювати свої думки, доводити і спростовувати їх. В основі цієї здатності лежать розвинені мис- 
леннєві операції, поняттєве мислення, уміння встановлювати причинно-наслідкові зв'язки, робити обгрунтовані висновки та мовлення.

Слід мати на увазі, що для підлітків важливо не просто бути разом з однолітками - вони прагнуть зайняти у їх середовищі те становище, яке б відповідало їхнім претензіям. Для одних це бажання бути лідером, для інших - користуватись авторитетом у якійсь справі, треті намагаються знайти близького друга тощо. Однак завжди це прагнення $\epsilon$ провідним мотивом поведінки у цьому віці $[10$, c. 90$]$.

Спілкування з однолітками дедалі більше виходить за межі шкільного життя і навчальної діяльності, охоплюючи нові інтереси, види діяльності, стосунки, виділяючись в окрему, самостійну і надзвичайно важливу для вихованця-підлітка сферу життя. Це пояснює, 3 одного боку, підвищений конформізм підлітків щодо компаній однолітків, i, з другого, їх недисциплінованість і навіть правопорушення через невміння досягти бажаного становища у таких компаніях [11, с. 78].

Основою міжособистісних стосунків $є$ привабливість однієї людини для іншої. Тому критерій задоволеності-незадоволеності виступає основним критерієм оцінки таких стосунків в межах підліток-дорослий, підлітокпідліток. На думку М. Обозова, привабливість складається 3 почуттів симпатії та притягання. Якщо симпатія-антипатія - це переживання задоволення та незадоволення від контак- тів 3 іншими людьми, то притяганнявідштовхування - практична складова цих переживань [5, с. 78].

Міжособистісна привабливістьнепривабливість може набувати характеру сталих зв'язків між підлітками й переходити у взаємну прихильність або неприхильність. Прагнення бути разом може стати потребою, i тоді ми говоримо про певний тип міжособистісних стосунків: приязних, дружніх, товариських.

У регуляції стосунків беруть участь три мотиваційні аспекти : «я хочу», «я можу» i «треба». Особистого бажання («я хочу») недостатньо для виникнення стосунків. Необхідне узгодження взаємних бажань і можливостей («я можу»). «Треба» - найважливіший аспект утворення, розвитку або руйнування стосунків. Так, дружні стосунки можуть зайти в суперечність із виробничими, моральними $[13$, c. 93].

Зміна поведінки, установок, оцінок виникає в процесі взаємного обміну думками, почуттями, вчинками. Взаємовплив характеризується подібністю, це сприяє поєднанню інтересів і ціннісних орієнтацій, тобто відбувається процес уподібнення членів однієї групи. Механізмами взаємовпливу є імітація, навіювання, конформність, переконання [1; 3; 6]. Зміст названих механізмів розкрито у таблиці 1.

Слід чітко розрізняти конформність як ситуативне явище та конформізм як рису ха- 
рактеру. Конформність виявляється в повсякденному житті, оскільки людині доводиться кілька основних умов. Велике значення в ступені конформності та переконаності має те,

Таблиия 1

Механізми взаємовпливу в міжособистісних стосунках вихованців-підлітків *

\begin{tabular}{|c|l|}
\hline $\begin{array}{c}\text { Механізми взає- } \\
\text { мовпливу }\end{array}$ & \multicolumn{1}{|c|}{ Характеристика } \\
\hline \multicolumn{1}{|c|}{ Імітація } & $\begin{array}{l}\text { Неспрямований вплив, що не ставить перед собою спеціальної цілі, але має кін- } \\
\text { цевий ефект і є найпростішою формою відображення людиною поведінки ін- } \\
\text { ших людей. На основі імітації формуютья інші регулятори взаємовпливу - на- } \\
\text { віювання, конформність, переконання. Вони регулюють норми міжособистісно- } \\
\text { го спілкування. Норми, у свою чергу, визначають характер міжособистісних } \\
\text { стосунків. Наявність відпрацьованих норм демонструє однозначність у розумін- } \\
\text { ні та оцінці подій. }\end{array}$ \\
\hline Навіювання & $\begin{array}{l}\text { Найменш усвідомлюваний процес - грунтується на некритичному наслідуванні } \\
\text { зразків поведінки іншої дитини. Навіювання може бути пряме (коли один із } \\
\text { партнерів по спілкуванню ставить перед собою таке завдання) і непряме, мимо- } \\
\text { вільне. }\end{array}$ \\
\hline Конформність & $\begin{array}{l}\text { впроцесом свідомої зміни оцінок, установок, поведінки під впливом групи. Це } \\
\text { виражається у свідомій зміні ціннісних орієнтацій, прийнятті групових норм, } \\
\text { очікувань та ролі, яку нав'язує група. Міра прийняття особистістю зовнішніх } \\
\text { оцінок і норм поведінки свідчить про ступінь ії конформності. Прийняття норм } \\
\text { може мати поверховий характер або ж глибинний, пов'язаний зі зміною диспо- } \\
\text { зицій особистості. }\end{array}$ \\
\hline Переконання & $\begin{array}{l}\text { Процес свідомого прийнятя оцінок, думок і стереотипів поведінки, що нале- } \\
\text { жать групі. У процесі переконання відбувається звертання в основному до раці- } \\
\text { ональних сторін психіки, досвіду, знань, логічного мислення, хоча все це не } \\
\text { виключає участі емоцій та почуттів. }\end{array}$ \\
\hline
\end{tabular}

*- складено автором на основі [1;3;6]

узгоджувати свою поведінку з іншими людьми, з певними соціальними нормами. Конформізм як особистісна риса - це готовність підлітка змінювати власну поведінку, роль, думки та переконання відповідно до нав'язаних їй норм, оцінок [12, с. 120].

Навіювання, конформність, переконання у повсякденному спілкуванні ідуть поряд. Вплив однолітка на підлітка $є$ процесом багатоплановим, але все ж таки можна виділити хто є суб'єктом впливу. Це залежить від соціального статусу особи, належність до певної організації, віку, професії тощо [4, с. 67].

Міжособистісні стосунки впливають на зміни характеру підлітка. У процесі спільного життя вихованці ДБСТ набувають як загальних рис, так і виробляють протилежні характерологічні властивості. Наявність у батька такої риси, як домінантність, формує в підлітка зворотної риси - пасивності, проте ця риса 
в матері позитивно впливає на формування цієї риси в дитини.

«Міжособистісне уподібнення» - це закономірність міжособистісних стосунків, що показує зближення психологічних рис у підлітків, цей термін називають ще законом, а часткове уподібнення - ефект «поляризації» особистісних рис - формування відбувається у процесі тривалих стосунків [12, с. 110].

Оцінка міжособистісних стосунків передбачає проведення їхньої класифікації. Так, виділяються стосунки знайомства, приятелювання, дружби, Коли один $з$ партнерів сприймає ці стосунки тільки як знайомство, а інший - як дружбу, то виникає непорозуміння. Тому міжособистісні стосунки можна визначити як взаємну готовність партнерів до певного типу почуттів, домагань, очікувань, поведінки [5, с. $120]$.

Охарактеризуємо критерії регулювання змісту міжособистісних стосунків. Головним критерієм регулювання змісту міжособистісних стосунків $є$ ступінь включення особистості в стосунки. Загально-видові, соціокультурні, психологічні, індивідуальні - основні характеристики особистості. Найбільше вираження індивідуальних характеристик особистості відбувається у стосунках знайомства, а приятелювання обмежуються включенням у взаємодію переважно видових та соціокультурних особливостей особистості [12, с. 130].

Другий критерій - вибірковість щодо партнерів - можна визначити як кількість оз- нак, що мають значення для встановлення та відтворення стосунків. Найбільшу вибірковість виявляють стосунки дружби, кохання, найменшу - знайомства. Середня кількість осіб, уведених у стосунки знайомства особистості, 150-500, приятелювання - 70-150, стосунки дружби охоплюють 2-3 особи [5, с. 124].

Т. Лірі, виділяє такі типи міжособистісних стосунків : 1) авторитарний; 2) егоїстичний; 3) агресивний; 4) підозріливий; 5) покірливий; 6) залежний; 7) доброзичливий; 8) альтруїстичний. Зміст названих типів розкрито у таблиці 2.

\section{Перелік використаних джерел:}

1.Вікова та педагогічна психологія: Навч. посібник. / За ред. О. В. Скрипченко, Л. В. Долинської, З. В. Огороднічук та ін. - К.: Просвіта, 2001. -416 с.

2. Доля I. М. Дитячі будинки сімейного типу: механізм подолання соціального сирітства в Україні / І. М. Доля // Стратегічні пріоритети. - 2009. - №2(11). - С. 195 199.

3. Заброцький М. М. Основи вікової психології. Навчальний посібник / М. М. Заброцький. - Тернопіль: Навчальна книга - Богдан, 2001. - 112 с.

4. Захист дітей, які потребують особливої уваги суспільства: стат. зб. [відп. за випуск І. В. Калачова]. - К.: Державний комітет статистики України, 2010. - 76 с

5. Конанко О. Соціально-емоційний розвиток особистості / О. Конанко. - К.: Освіта, 1998. - 255 с.

6. Кутішенко В. П. Вікова та педагогічна психологія (курс лекцій): Навчальний посібник / В. П. Кутішенко. - Київ: Центр навчальної літератури, 2005. - 128 с.

7. Лактіонова Г. Створення та соціальний супровід прийомних сімей і дитячих будинків сімейного типу / 
Г. Лактіонова, Ж. Петрочко, А. Калініна та інші. - Київ: Наук. світ, 2006. - 270 с.

8. Малькова М. О. Формування позитивних міжособистісних стосунків підлітків у колективі однолітків / М. О. Малькова. [Електронний ресурс]. - Режим доступу: http://www.stattionline.org.ua/pedagog/104/17660formuvannya-pozitivnix-mizhosobistisnix-stosunkivpidlitkiv-u-kolektivi-odnolitkiv.html.

9. Накопичена О. В. Конфліктність як чинник міжособистісних стосунків / О. В. Накопичена // Вісник Київського Національного Університету ім. Т. Шевченка. Соціологія. Психологія. Педагогіка. - 2003. - №15-16.

10. Савчин М. В. Вікова психологія: Навчальний посібник / М. В. Савчин, Л. П. Василенко. - К.: Академвидав, 2005. - 360 с.

11. Створення та соціальний супровід прийомних сімей і дитячих будинків сімейного типу : навч.-метод. посіб. / упоряд.: Г. Лактіонова, Ж. Петрочко, А. Калініна та ін. - Київ: Наук. світ, 2006. - 270 с.

12. Тунтуєва C. Соціально-педагогічна робота з прийомною сім'єю та дитячим будинком сімейного типу / С. Тунтуєва // Соціально-педагогічна підтримка сім’ї 3 дитиною: матеріали всеукр. наук.-практ. семінару, 20 березня 2014 р. - Запоріжжя: Запорізьк. нац. ун-т, 2014. - C. 78-79.

13. Пєша I. В. Дитячі будинки сімейного типу як особлива форма сімейної опіки над дітьми-сиротами, позбавленими батьківського піклування / І. В. Пєша // Український соціум. - 2012. - № 1 (2). - С.72-80.

14. Собчик Л. М. Діагностика міжособистісних відносин: модифікований варіант інтерперсональної діагностики Т. Лірі / Л. М. Собчик. - М.: ИНФРА, 1990. - 156 c.

15. Ясеновська М. Права вихованців в дитячих будинках сімейного типу України / М. Ясеновська, О. Білецька. - Харків, 2004. - 152 с.

\section{References (Transliteration):}

1. Vikova ta pedahohichna psykholohiia: Navch posibnyk. / Za red. O. V. Skrypchenko, L. V. Dolynskoi, Z. V. Ohorodnichuk ta in. - K.: Prosvita, 2001. -416 s.

2. Dolia I. M. Dytiachi budynky simeinoho typu: mekhanizm podolannia sotsialnoho syritstva v Ukraini / I. M. Dolia // Stratehichni priorytety. - 2009. - №2(11). - S. 195199.

3. Zabrotskyi M. M. Osnovy vikovoi psykholohii. Navchalnyi posibnyk / M. M. Zabrotskyi. - Ternopil: Navchalna knyha - Bohdan, 2001. - $112 \mathrm{~s}$.

4. Zakhyst ditei, yaki potrebuiut osoblyvoi uvahy suspilstva: stat. zb. [vidp. za vypusk I. V. Kalachova]. - K.: Derzhavnyi komitet statystyky Ukrainy, 2010. - $76 \mathrm{~s}$

5. Konanko O. Sotsialno-emotsiinyi rozvytok osobystosti / O. Konanko. - K.: Osvita, 1998. - 255 s.

6. Kutishenko V. P. Vikova ta pedahohichna psykholohiia (kurs lektsii): Navchalnyi posibnyk / V. P. Kutishenko. Kyiv: Tsentr navchalnoi literatury, 2005. - $128 \mathrm{~s}$.

7. Laktionova H. Stvorennia ta sotsialnyi suprovid pryiomnykh simei i dytiachykh budynkiv simeinoho typu / H. Laktionova, Zh. Petrochko, A. Kalinina ta inshi. - Kyiv: Nauk. svit, 2006. $-270 \mathrm{~s}$.

8. Malkova M. O. Formuvannia pozytyvnykh mizhosobystisnykh stosunkiv pidlitkiv u kolektyvi odnolitkiv / M. O. Malkova. [Elektronnyi resurs]. - Rezhym dostupu: http://www.stattionline.org.ua/pedagog/104/17660 -formuvannya-pozitivnix-mizhosobistisnix-stosunkivpidlitkiv-u-kolektivi-odnolitkiv.html.

9. Nakopychena $O$. $V$. Konfliktnist yak chynnyk mizhosobystisnykh stosunkiv / O. V. Nakopychena // Visnyk Kyivskoho Natsionalnoho Universytetu im. T. Shevchenka. Sotsiolohiia. Psykholohiia. Pedahohika. - 2003. - №15-16. 10. Savchyn M. V. Vikova psykholohiia: Navchalnyi posibnyk / M. V. Savchyn, L. P. Vasylenko. - K.: Akademvydav, 2005. - $360 \mathrm{~s}$.

11. Stvorennia ta sotsialnyi suprovid pryiomnykh simei i dytiachykh budynkiv simeinoho typu : navch.-metod. posib. / uporiad.: H. Laktionova, Zh. Petrochko, A. Kalinina ta in. - Kyiv: Nauk. svit, 2006. -270 s.

12. Tuntuieva $S$. Sotsialno-pedahohichna robota z pryiomnoiu simieiu ta dytiachym budynkom simeinoho typu / S. 
Tuntuieva // Sotsialno-pedahohichna pidtrymka simi z dytynoiu: materialy vseukr. nauk.-prakt. seminaru, 20 bereznia 2014 r. - Zaporizhzhia: Zaporizk. nats. un-t, 2014. - S. 78-79.

13. Piesha I. V. Dytiachi budynky simeinoho typu yak osoblyva forma simeinoi opiky nad ditmy-syrotamy, pozbavlenymy batkivskoho pikluvannia / I. V. Piesha // Ukrainskyi sotsium. - 2012. - № 1 (2). - C.72-80.

14. Sobchyk L. M. Diahnostyka mizhosobystisnykh vidnosyn: modyfikovanyi variant interpersonalnoi diahnostyky T. Liri / L. M. Sobchyk. - M.: YNFRA, 1990. - 156 s.

15. Yasenovska M. Prava vykhovantsiv V dytiachykh budynkakh simeinoho typu Ukrainy / M. Yasenovska, O. Biletska. - Kharkiv, 2004. - 152 s.

\section{Chystyak Olga}

Graduate student of psychology and pedagogy, Faculty of Education and Psychology, National Pedagogical Dragomanov University, Kyiv (Ukraine)

\section{PSYCHOLOGICAL MECHANISMS OF FORMATION OF INTERPERSONAL RELATIONS AMONG PUPILS AND ADOLESCENTS CHILDREN'S HOME OF FAMILY TYPE}

\section{ABSTRACT}

The article presents the theoretical analysis of scientific studies of interpersonal communication in adolescence. The features of mutual relations of pupils and adolescents children's home of family type. The structure of formation of interpersonal relations. Presents a description of the types of interpersonal relationships in adolescence. The article describes the mechanisms of formation of interpersonal relations of students-adolescents in a family-type orphanage. Characterized by interpersonal relationships between peers, parents, caregivers, foster children second. The mechanisms of interaction in interpersonal relationships students - teenagers. The disclosed algorithm of formation of interpersonal relations of pupils - adolescents on the basis of democratic parenting style in the children's home of family type. The components of interpersonal relationships and disclosure of their contents.

Key words: interpersonal relationships; adolescence; the structure for the formation of interpersonal relationships; mechanisms of interpersonal relations.

\section{Чистяка Ольга Владимировна}

Аспирант кафедры психологии и педагогики факультета педагогики и психологии, НПУ имени М. П. Драгоманова, Киев (Украина)

\section{ПСИХОЛОГИЧЕСКИЕ МЕХАНИЗМЫ ФОРМИРОВАНИЯ МЕЖЛИЧНОСТНЫХ ОТНОШЕНИЙ У ВОСПИТАННИКОВ-ПОДРОСТКОВ ДЕТСКОГО ДОМА СЕМЕЙНОГО ТИПА}

Аннотация. В статье осуществлен теоретический анализ научных исследований межличностного общения в подростковом возрасте. Определены особенности взаимоотношений воспитанников-подростков детского дома семейного типа. Проанализирована структура формирования межличностных отношений. Представленная характеристика типов межличностных взаимоотношений в подростковом возрасте. В статье рассмотрены механизмы 
формирования межличностных отношений воспитанников-подростков в условиях детского дома семейного типа. Охарактеризованы межличностные отношения между сверстниками, родителями-воспитателями, вторыми приемными детьми. Рассмотрены механизмы взаимовлияния в межличностных отношениях воспитанников - подростков. Раскрыт алгоритм формирования межличностных отношений воспитанников - подростков на основе демократического стиля воспитания в детском доме семейного типа. Представлены компоненты межличностных отношений и раскрыто их содержание.

Ключевые слова: межличностные отношения; подростковый возраст; структура формирования межличностных взаимоотношений; механизмы межличностных отношений. 